\title{
Anti-idiotypic Antibodies Prevent the Serologic Detection of Antiribosomal P Autoantibodies in Healthy Adults
}

\author{
Zi-Jian Pan, Camille J. Anderson, and Haraldine A. Stafford \\ Arthritis and Immunology Program, Oklahoma Medical Research Foundation, Department of Medicine, University of Oklahoma Health \\ Sciences Center, Department of Veterans Affairs Medical Center, Oklahoma City, Oklahoma 73104
}

\begin{abstract}
A subset of SLE patients has serologically detectable autoantibodies to the ribosomal $\mathrm{P}$ proteins (anti-P). We reported the discovery of covert anti-P antibodies and their masking IgG-inhibitory antibodies in the sera of healthy adults. The aim of this study was to determine if these IgGinhibitory antibodies are anti-idiotypic antibodies (anti-Ids). IgG and IgG-depleted fractions of plasma from two healthy adults were assayed for inhibition of anti-P $\mathrm{F}\left(\mathrm{ab}^{\prime}\right)_{2}$ binding to the ribosomal $P$ proteins in immunoblot. Anti-P antibody activity was completely inhibited by plasma IgG, whereas there was no inhibition by IgG-depleted plasma. IgG-inhibitory antibodies recognized a cross-reactive epitope among anti-P from different SLE patients. Plasma IgG from one healthy adult was depleted of pepsin agglutinators and generic anti-F $\left(\mathrm{ab}^{\prime}\right)_{2}$ antibodies by adsorption with an affinity column prepared with normal IgG $\mathrm{F}\left(\mathrm{ab}^{\prime}\right)_{2}$. Unretained IgG bound exclusively to anti-P $\mathrm{F}\left(\mathrm{ab}^{\prime}\right)_{2}$ in ELISA. Using four affinity columns, we isolated IgG anti-Ids to anti-P antibodies from four healthy adults. These purified anti-Ids bound to anti-P $\mathrm{F}\left(\mathrm{ab}^{\prime}\right)_{2}$ from a healthy adult and SLE patients. They did not bind to $\mathrm{F}\left(\mathrm{ab}^{\prime}\right)_{2}$ fragments prepared from normal IgG or anti-dsDNA. Ribosomal antigens blocked this antiId-Id interaction. Purified anti-Ids inhibited the binding of anti-P $\mathrm{F}\left(\mathrm{ab}^{\prime}\right)_{2}$ from patients to ribosomal $\mathrm{P}$ proteins. SLE patients without overt anti-P antibodies also possessed IgG anti-Ids to anti-P antibodies. We conclude that IgG-inhibitory antibodies are anti-Ids to anti-P antibodies, and are directed to public idiotopes on anti-P antibodies. These anti-Ids may be part of an Id network that regulates anti-P antibody expression, and perhaps pathogenicity. (J. Clin. Invest. 1998. 102:215-222.) Key words: anti-idiotypic antibodies • ribosomal proteins $\cdot \mathrm{SLE} \cdot$ human $\bullet$ autoantibodies
\end{abstract}

\section{Introduction}

SLE is a clinically diverse disease that is characterized by the presence of serologically detectable, i.e., overt, autoantibodies to self-antigens. A subset of these autoantibodies has diagnostic, prognostic, and pathogenic significance in SLE. Recent

Address correspondence to Haraldine A. Stafford, Ph.D., M.D., Oklahoma Medical Research Foundation, 825 N.E. 13th Street, MS \#24, Oklahoma City, OK 73104. Phone: 405-271-7217; FAX: 405-2714110; E-mail: DeeDee-Stafford@omrf.ouhsc.edu

Received for publication 9 October 1997 and accepted in revised form 23 April 1998.

The Journal of Clinical Investigation

Volume 102, Number 1, July 1998, 215-222

http://www.jci.org evidence suggests that the antiribosomal $\mathrm{P}$ autoantibodies (anti-P) ${ }^{1}$ have such clinical and pathologic relevance.

Ribosomal P proteins comprise a family of acidic phosphoproteins that are the target antigens for anti-P antibodies. These autoantibodies react predominantly to a shared epitope at carboxyl-termini of the ribosomal $\mathrm{P}$ proteins (1). Anti-P antibodies are highly specific for $\operatorname{SLE}(1,2)$, and their presence frequently correlates with disease activity, in particular psychotic depression (2), hepatitis (3-5), and nephritis (4, 6). These autoantibodies have been detected in up to $42 \%$ of patients with active disease (7; Chindalore, V., B.R. Neas, and M. Reichlin, manuscript submitted for publication) and levels of anti-P antibodies have been shown to decrease with disease remission $(3,6)$. Studies in animals (8) and in vitro (9-11) suggest that anti-P antibodies may be cytopathic.

Healthy individuals rarely display overt anti-P antibodies (12). However, we recently discovered that anti-P antibodies exist in a masked state in virtually all healthy adults (12). These covert anti-P antibodies are detected only after treatment of serum with immobilized ribosomal $\mathrm{P}$ antigens $(12,13)$. These autoantibodies are of the IgG isotype, and they appear indistinguishable from those of SLE patients. Their activity in ELISA and immunoblot is inhibited by $\mathrm{IgG}$ antibodies in normal serum and plasma. Inhibitory activity is associated only with $\mathrm{IgG}$, and not with antigen-containing IgG immune complexes.

We hypothesized that these IgG-inhibitory antibodies are anti-idiotypic antibodies (anti-Ids) to anti-P antibodies. Such anti-Ids would prevent serologic detection and pathogenicity of anti-P antibodies in healthy individuals. The aim of this study was to demonstrate in healthy individuals that IgG antibodies to anti-P antibodies are idiotype specific, and are responsible for the lack of detection of their anti-P antibodies.

\section{Methods}

Sample collection. Samples of either plasma, sera, or both were obtained from four healthy adult donors and 24 adult SLE patients. No healthy adult had an acute or chronic illness, nor were they taking medication. All patients fulfilled diagnostic criteria for SLE as defined by the American College of Rheumatology (14). Anti-P antibody positivity was determined by immunoblot and ELISA as described (15). Samples from multiple dates were available on most patients, and were repeatedly negative for anti-P antibodies in $10 \mathrm{pa}-$ tients. Samples from the remaining patients were either persistently

1. Abbreviations used in this paper: Ab2, anti-idiotypic antibodies; anti-dsDNA, anti-double-stranded DNA autoantibodies; anti-Ids, anti-idiotypic antibodies; anti-P, antiribosomal P autoantibodies; CF II, Cohn Fraction II; dCF II F $\left(\mathrm{ab}^{\prime}\right)_{2}$, anti-P-depleted CF II F $\left(\mathrm{ab}^{\prime}\right)_{2}$; GST-P2, recombinant fusion protein consisting of human ribosomal P2 and glutathione S-transferase proteins; IgG, immunoglobulin G. 
or intermittently positive. Three patients, $1-3$, had high titers of anti-P antibodies, as demonstrated by HEp- 2 immunofluorescence and gel diffusion analyses. All samples were stored at $-20^{\circ} \mathrm{C}$ before use.

Preparation of antigen and antigen immunosorbents. Ribosomes were prepared from freshly isolated rabbit livers and assayed for antigenicity as described (12). A ribosome-immunosorbent column was prepared by coupling ribosomes to Sepharose CL-4B (Pharmacia Fine Chemicals, Uppsala, Sweden) as described (12).

The recombinant human ribosomal $\mathrm{P} 2$ protein was prepared as a fusion protein to glutathione S-transferase (GST-P2). The cDNA encoding the full-length ribosomal P2 protein was the generous gift of Dr. Keith Elkon (Hospital for Special Surgery, Cornell University, New York). This cDNA was subcloned into the pGEX3X expression vector of the GST Gene Fusion System (Pharmacia Fine Chemicals). GST-P2 was expressed in Escherichia coli DH5 $\alpha$ after induction with isopropyl-thio- $\beta$-D-galactoside. The protein was affinity purified from bacterial cell lysate supernatants by glutathione-Sepharose 4B beads (Pharmacia). A GST-P2 immunosorbent column was prepared by coupling GST-P2 to 3M Emphaze beads (Pierce Chemical Co., Rockford, IL), according to the manufacturer's instructions.

Purification of anti-P autoantibodies. Anti-P antibodies were purified from plasma of SLE patients 1-3 and a healthy adult by affinity chromatography on ribosome and GST-P2 immunosorbents, respectively, as described (12). Columns were exhaustively regenerated between individuals. Anti-P antibodies were also purified from the sera of 10 anti-P-negative SLE patients by affinity purification on nitrocellulose membranes coated with ribosomal $\mathrm{P}$ proteins as described (15). The presence of anti-P antibodies in the eluted material was confirmed with either the multiple antigenic peptide-"P-peptide"specific ELISA (16), the ribosome-specific immunoblot, or both (12).

Preparation of IgG and IgG-depleted fractions of plasma. IgG was separately purified from the plasma of healthy adults 1 and 2 by affinity chromatography on protein G-Sepharose Fast Flow (Sigma Chemical Co., St. Louis, MO) and by multiple cycles of ammonium sulfate precipitation as described (17). Both purification schemes generated IgG fractions of comparable purity, as assessed by SDSPAGE. The IgG-depleted fraction from healthy adult 1 was reapplied to protein $\mathrm{G}$ to eliminate any residual IgG. IgG and IgG-depleted fractions were dialyzed against PBS. IgG concentrations were determined by IgG-specific ELISA (12). Protein concentration of the IgGdepleted fraction was determined by protein assay (Bio-Rad Laboratories, Hercules, CA).

IgG anti-P antibodies from SLE patient 1 were prepared by application of the patient's affinity-purified anti-P antibodies to a protein $\mathrm{G}$ column. This column was used exclusively for patients.

Preparation of antibody fragments and $F\left(a b^{\prime}\right)_{2}$ immunosorbents. $\mathrm{F}\left(\mathrm{ab}^{\prime}\right)_{2}$ fragments were prepared by pepsin digestion (18) of affinitypurified anti-P antibodies from three patients and one healthy adult, and normal $\mathrm{IgG}$ from three sources (plasma $\mathrm{IgG}$ from each healthy adult and Cohn Fraction II [CF II; Sigma Chemical Co.]). Before pepsin digestion, normal IgG was depleted of anti-P antibodies by passage through a ribosome immunosorbent column, and collection of unretained fractions. All $\mathrm{F}\left(\mathrm{ab}^{\prime}\right)_{2}$ fragments were devoid of contaminating $\mathrm{Fc}$ fragments, as assessed by SDS-PAGE and Fc-specific ELISA. In the latter test, $\mathrm{F}\left(\mathrm{ab}^{\prime}\right)_{2}$ fragments and undigested normal IgG were used to coat wells, and alkaline phosphatase-conjugated goat anti-human IgG (Fcy-specific; Jackson Immunoresearch, West Grove, PA) was added. IgG anti-P $\mathrm{F}\left(\mathrm{ab}^{\prime}\right)_{2}$ fragments from patient 1 and anti-P-depleted CF II F $\left(\mathrm{ab}^{\prime}\right)_{2}$ fragments (dCF II F $\left.\left(\mathrm{ab}^{\prime}\right)_{2}\right)$ were coupled to 3M Emphaze (Pierce Chemical Co.) and Sepharose CL4B (Pharmacia Fine Chemicals), respectively.

$\mathrm{F}\left(\mathrm{ab}^{\prime}\right)_{2}$ fragments of autoantibodies to double-stranded DNA (anti-dsDNA) were the generous gift of Dr. Wei Zhang (Oklahoma Medical Research Foundation, Oklahoma City, OK). These affinitypurified anti-dsDNA antibodies were from the serum of a SLE patient.

$\mathrm{Fab}^{\prime}$ fragments were prepared from purified $\mathrm{F}\left(\mathrm{ab}^{\prime}\right)_{2}$ fragments of anti-P antibodies from SLE patient 1 by reduction with $1 \mathrm{mM}$ dithio- threitol for $1.5 \mathrm{~h}$ at room temperature, followed by alkylation with 1 $\mathrm{mM}$ iodoacetamide for $30 \mathrm{~min}$ at room temperature. All fragments were dialyzed against PBS, and assessed for purity by SDS-PAGE.

Purification of IgG antibodies to anti-P $F\left(a b^{\prime}\right)_{2}$. Plasma samples from each healthy adult that were prepared in $0.5 \mathrm{M} \mathrm{NaCl}$ were applied to the IgG anti-P F $\left(\mathrm{ab}^{\prime}\right)_{2}$ immunosorbent column. The unretained plasma was collected, concentrated, and dialyzed against PBS. After extensive washing of the column with $0.02 \mathrm{M}$ Tris-HCl/0.5 M $\mathrm{NaCl} / 0.05 \% \mathrm{NaN}_{3}, \mathrm{pH} 7.4$, bound material was eluted with $3 \mathrm{M} \mathrm{MgCl}_{2}$, $\mathrm{pH}$ 6.5, and dialyzed against PBS. This material was sequentially passed through GST-P2 and dCF II F $\left(\mathrm{ab}^{\prime}\right)_{2}$ immunosorbent columns. These steps would remove anti-P antibodies that may have leached off the IgG anti-P $\mathrm{F}\left(\mathrm{ab}^{\prime}\right)_{2}$ column and any other serum components that might bind to normal $\mathrm{IgG}$, for example, pepsin agglutinators (19) and generic anti- $\mathrm{F}\left(\mathrm{ab}^{\prime}\right)_{2}$ antibodies (20). The unretained material underwent protein $\mathrm{G}$ chromatography to remove any potential contaminating soluble antigen. A second set of identical columns was used to isolate anti-Ids to anti-P antibodies from SLE patients 3 and 4. Purified IgG antibodies to anti-P F $\left(\mathrm{ab}^{\prime}\right)_{2}$ were dialyzed against PBS. Their purity was assessed by SDS-PAGE and was almost exclusively IgG.

Preparation of pepsin agglutinator- and generic anti- $F\left(a b^{\prime}\right)_{2^{-}}$ depleted plasma IgG. Plasma IgG from healthy adult 1 that was prepared by ammonium sulfate precipitation was passed through the $\mathrm{dCF}$ II F $\left(\mathrm{ab}^{\prime}\right)_{2}$ immunosorbent column. Unbound IgG was dialyzed against PBS.

Analysis of anti-P antibody activity by ribosome-specific immunoblotting. Reactivity with membrane-bound proteins from purified rabbit ribosomes was assayed as described (12). Anti-P antibodies were detected with alkaline phosphatase-conjugated $\gamma$-chain-specific polyclonal goat anti-human IgG (Southern Biotechnology Associates, Birmingham, AL) or $\mathrm{F}\left(\mathrm{ab}^{\prime}\right)_{2}$-specific anti-human IgG (Jackson Immunoresearch).

Inhibition of anti-P antibody activity was tested by preincubation of anti-P antibodies with putative inhibitors or PBS for $4 \mathrm{~h}$ at room temperature, followed by incubation with membrane-bound ribosomal proteins. Immunoblots were scanned with a desktop scanner (Hewlett Packard, Palo Alto, CA), and densitometric analyses were performed using NIH Image. ${ }^{2}$

Analysis of anti-Id antibody activity by $F\left(a b^{\prime}\right)_{2}$-specific ELISA. 96-well ELISA plates were divided into two or more parts, depending on the number of $\mathrm{F}\left(\mathrm{ab}^{\prime}\right)_{2}$ samples to be tested. For each experiment, wells were coated with $\mathrm{F}\left(\mathrm{ab}^{\prime}\right)_{2}$ preparations of anti-P, dCF II, or antidsDNA antibodies. All $\mathrm{F}\left(\mathrm{ab}^{\prime}\right)_{2}$ samples were prepared in $0.15 \mathrm{M}$ $\mathrm{Na}_{2} \mathrm{CO}_{3}, 0.35 \mathrm{M} \mathrm{NaHCO}_{3}, \mathrm{pH} 9.6$, and were incubated on the plate for $2 \mathrm{~h}$ at room temperature. The appropriate concentration of $\mathrm{F}\left(\mathrm{ab}^{\prime}\right)_{2}$ for coating was determined by measurement of their binding in ELISA to alkaline phosphatase-conjugated $\mathrm{F}\left(\mathrm{ab}^{\prime}\right)_{2}$-specific antihuman IgG (Jackson Immunoresearch). Concentrations of $\mathrm{F}\left(\mathrm{ab}^{\prime}\right)_{2}$ that gave equal anti-F $\left(\mathrm{ab}^{\prime}\right)_{2}$ binding were used, and corresponded to $1.25-5 \mu \mathrm{g} / \mathrm{ml}$. Plates were subsequently washed with PBS containing $0.05 \%$ Tween $20, \mathrm{pH} 7.4$, and remaining protein sites were blocked with $0.1 \%$ BSA in PBS, pH 7.4, for at least $1 \mathrm{~h}$. After washing, sources of anti-Ids to anti-P antibodies were added to wells containing each of the $\mathrm{F}\left(\mathrm{ab}^{\prime}\right)_{2}$ preparations. Sources consisted of plasma IgG from healthy adult 1 that was depleted of pepsin agglutinators and generic anti-F $\left(\mathrm{ab}^{\prime}\right)_{2}$ antibodies, and affinity-purified $\mathrm{IgG}$ antibodies to anti-P F $\left(\mathrm{ab}^{\prime}\right)_{2}$. These samples were prepared in PBS, pH 7.4, containing $0.1 \%$ BSA and $0.05 \%$ Tween 20 . Incubation was for $2 \mathrm{~h}$ at room temperature. After washing, alkaline phosphatase-conjugated $\gamma$-chainspecific goat anti-human IgG (Sigma Chemical Co.) was added, incubated overnight at $4^{\circ} \mathrm{C}$, and followed by the addition of $p$-nitrophenyl phosphate (Sigma Chemical Co.). Optical density at $410 \mathrm{~nm}$ was de-

2. This program was developed at the United States National Institutes of Health, and is available on the Internet at http://rsb.info.nih. gov/nih-image/. 
termined with a microplate reader (model MRX; Dynatech, Alexandria, VA).

In inhibition experiments with fluid-phase $\mathrm{F}\left(\mathrm{ab}^{\prime}\right)_{2}$ fragments, IgG antibodies to anti-P $\mathrm{F}\left(\mathrm{ab}^{\prime}\right)_{2}$ were preincubated with soluble $\mathrm{F}\left(\mathrm{ab}^{\prime}\right)_{2}$ or PBS for $4 \mathrm{~h}$ at room temperature before their addition to the ELISA wells. In inhibition experiments with fluid-phase cognate antigen, anti-P F $\left(\mathrm{ab}^{\prime}\right)_{2}$-coated and blocked wells were preincubated with $50 \mu \mathrm{l}$ ribosomes or rabbit serum albumin (Sigma Chemical Co.) for $4 \mathrm{~h}$ at room temperature, then washed before the addition of $\mathrm{IgG}$ antibodies to anti-P $\mathrm{F}\left(\mathrm{ab}^{\prime}\right)_{2}$.

\section{Results}

Characterization of the inhibitory antibodies to anti-P antibodies in plasma IgG. Sera and plasma from healthy individuals have $\mathrm{IgG}$ antibodies to anti-P antibodies that inhibit antigen binding $(12,15)$. To determine which portion of the anti-P antibody was reactive with these inhibitory antibodies, inhibition was tested against $\mathrm{F}\left(\mathrm{ab}^{\prime}\right)_{2}$ fragments of anti-P. As a source of inhibitor, plasma was used instead of serum, which reduces the potential contamination by intracellular ribosomal proteins during blood coagulation. IgG and IgG-depleted fractions were prepared from plasma of healthy adult 1 by protein $G$ affinity chromatography. SDS-PAGE showed that the IgG fraction was as pure as a commercial IgG preparation, and the IgG-depleted fraction was free of IgG (Fig. $1 A$ ). IgG-specific ELISA corroborated these findings. Each fraction prepared by protein $\mathrm{G}$ chromatography was assayed for inhibition of anti-P antibody activity in a ribosome-specific immunoblot. Plasma IgG inhibited antigen reactivity of anti-P antibodies from SLE patient 1. Inhibition occurred in a concentration-dependent manner, with $100 \%$ inhibition at $900 \mu \mathrm{g} / \mathrm{ml} \mathrm{IgG} \mathrm{(see} \mathrm{Fig.} \mathrm{1,} \mathrm{B}$ and $C$ for inhibition of ribosomal $\mathrm{P} 0$ reactivity; comparable results were observed for ribosomal $\mathrm{P} 1$ and $\mathrm{P} 2$ proteins). In contrast, the IgG-depleted fraction lacked inhibitory activity. Plasma IgG from healthy adult 2 showed similar findings. Thus, plasma from healthy adults contain IgG antibodies that react with the $\mathrm{F}\left(\mathrm{ab}^{\prime}\right)_{2}$ portion of anti-P antibodies.

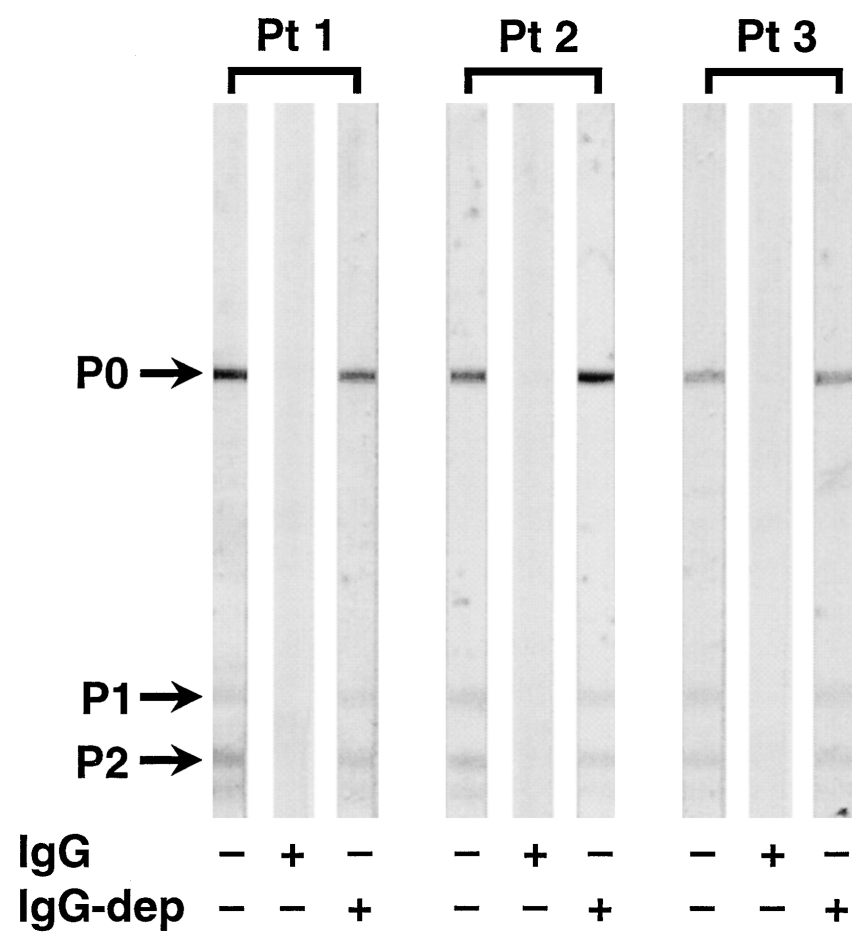

Figure 2. Recognition of a cross-reactive epitope among anti-P antibodies by plasma IgG. Anti-P F $\left(\mathrm{ab}^{\prime}\right)_{2}$ preparations from three SLE patients (at $0.25 \mu \mathrm{g} / \mathrm{ml}$ ) were preincubated with PBS (first lane in each set), plasma IgG (second lane in each set), or IgG-depleted (IgG-dep) plasma (third lane in each set) before analysis. Plasma fractions were from healthy adult 1 , and were used at $0.5 \mathrm{mg} / \mathrm{ml}$. Anti-P antibody activity was assayed as in Fig. 1 B. Arrows point to the ribosomal $\mathrm{P}$ proteins.

The cross-reactivity of these IgG-inhibitory antibodies for anti-P antibodies from different patients was investigated. Plasma fractions from healthy adult 1 were tested for inhibitory activity against the $\mathrm{F}\left(\mathrm{ab}^{\prime}\right)_{2}$ fragments of anti-P antibodies
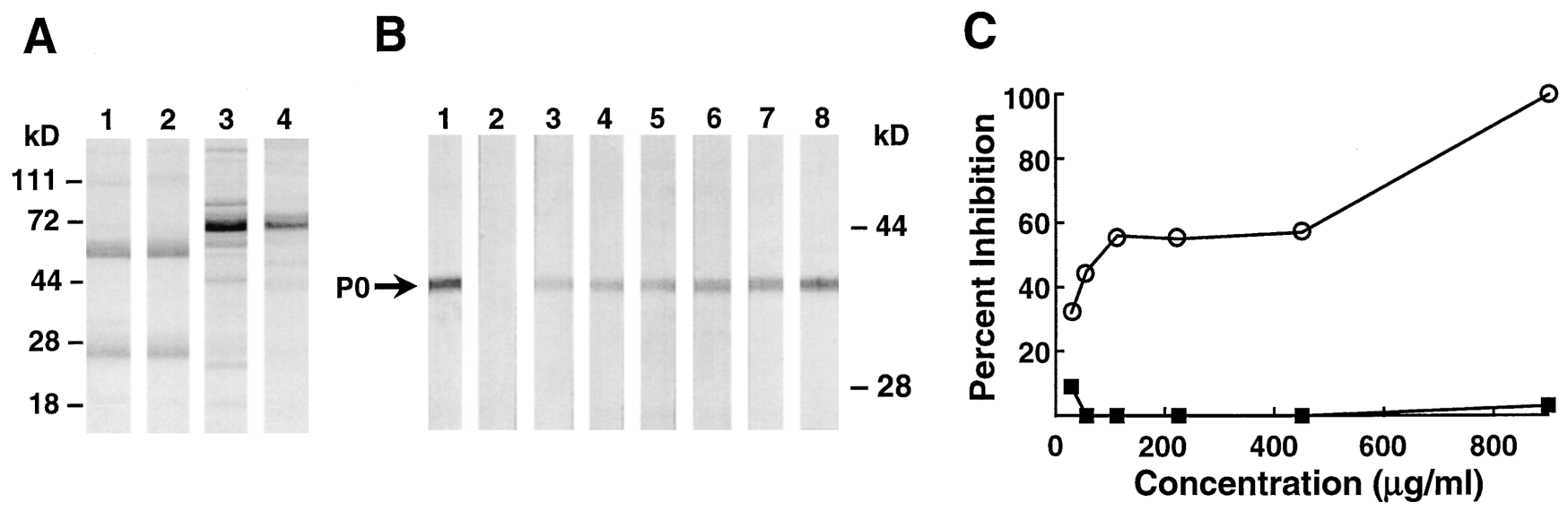

Figure 1. Inhibition of anti-P antibody activity with plasma IgG from healthy adult 1. (A) SDS-PAGE analysis of purified plasma IgG and IgGdepleted plasma. Samples were prepared under reducing conditions. Lanes 1 and 4 correspond to $\operatorname{IgG}$ and human serum albumin standards from Sigma Chemical Co. Lanes 2 and 3 correspond to plasma IgG and IgG-depleted plasma, respectively. (B) Assay for inhibition of anti-P F(ab' $)_{2}$ activity. Anti-P F $\left(\mathrm{ab}^{\prime}\right)_{2}$ from patient 1 at $0.25 \mu \mathrm{g} / \mathrm{ml}$ were incubated with plasma IgG at the indicated concentrations, and subsequently analyzed by ribosome-specific immunoblot. Lanes $1-7$ correspond to $0,900,450,225,112,56$, and $28 \mu \mathrm{g} / \mathrm{ml}$ of plasma IgG, respectively. Lane 8 corresponds to $900 \mu \mathrm{g} / \mathrm{ml}$ of IgG-depleted plasma. Arrow points to the ribosomal P0 protein. $(C)$ Results from densitometric analysis of immunoblots in $B$ and those prepared with the IgG-depleted plasma (data not shown except for the highest concentration tested) with $\bigcirc$ representing plasma $\mathrm{IgG}$ and $(\mathbf{\square})$ representing $\mathrm{IgG}-$ depleted plasma. 


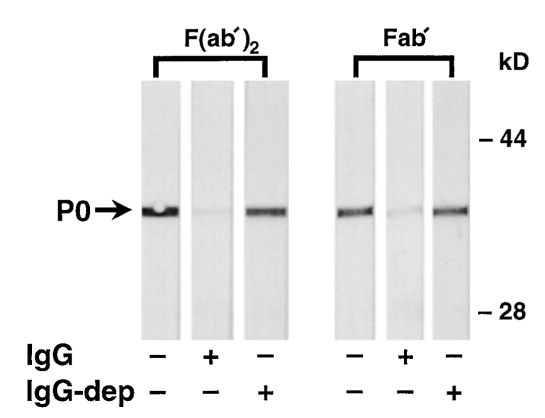

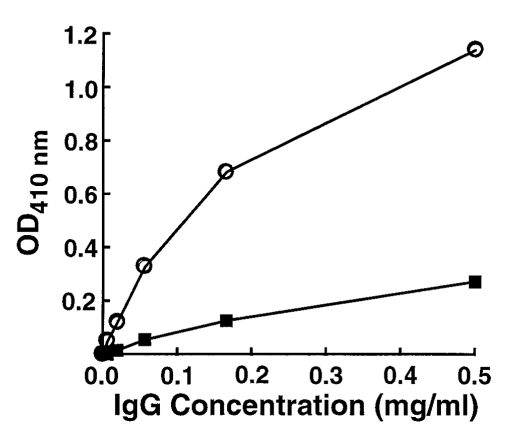

Figure 3. Epitope mapping of IgG-inhibitory antibodies to anti-P. $(A)$ Ribosome-specific immunoblots were probed with $\mathrm{F}\left(\mathrm{ab}^{\prime}\right)_{2}$ or $\mathrm{Fab}^{\prime}$ fragments of anti-P from patient 1 (at $1 \mu \mathrm{g} / \mathrm{ml})$ that had been preincubated with PBS, plasma IgG, or IgG-depleted plasma from healthy adult 1 (both at $1 \mathrm{mg} / \mathrm{ml}$ ) as described in Fig. 2. Arrow points to the ribosomal $\mathrm{P} 0$ protein. $(B)$ Plasma IgG from healthy adult 1 , which was depleted of pepsin agglutinators and generic anti- $\mathrm{F}\left(\mathrm{ab}^{\prime}\right)_{2}$ antibodies was assayed by ELISA for binding to $\mathrm{F}\left(\mathrm{ab}^{\prime}\right)_{2}$ fragments prepared from patient 1 's anti-P antibodies (O) and CF II ( $\mathbf{\square})$. from two additional SLE patients. Plasma IgG inhibited comparably the antigen reactivity of anti-P $\mathrm{F}\left(\mathrm{ab}^{\prime}\right)_{2}$ fragments from three patients (Fig. 2). Controls with IgG-depleted plasma did not show any inhibition. These data suggest that IgG-inhibitory antibodies might recognize a cross-reactive or public idiotope on anti-P antibodies.

IgG-inhibitory antibodies could potentially react with various epitopes within the $\mathrm{F}\left(\mathrm{ab}^{\prime}\right)_{2}$ fragments of anti-P antibodies, such as those within the hinge region or Fab portion of the antibody molecule. Plasma fractions from healthy adult 1 were tested for inhibition against isolated $\mathrm{Fab}^{\prime}$ fragments of anti-P antibodies from SLE patient 1. Plasma IgG inhibited the Fab' almost as effectively as it inhibited the $\mathrm{F}\left(\mathrm{ab}^{\prime}\right)_{2}$ fragment (Fig. 3 A). IgG-depleted plasma did not inhibit either fragment. Artifactual binding might be due to pepsin agglutinators (antibodies that react with a neoepitope generated on $\mathrm{IgG}$ molecules upon pepsin digestion) or generic anti-F( $\left(\mathrm{ab}^{\prime}\right)_{2}$ antibodies. To eliminate such binding, plasma IgG from healthy adult 1 was passed through an immunosorbent column prepared with dCF II $\mathrm{F}\left(\mathrm{ab}^{\prime}\right)_{2}$. Unretained $\mathrm{IgG}$ was then assayed for binding to $\mathrm{F}\left(\mathrm{ab}^{\prime}\right)_{2}$ fragments of anti-P antibodies from patient 1 . Binding to anti-P $\mathrm{F}\left(\mathrm{ab}^{\prime}\right)_{2}$ was four- to sixfold greater than binding to $\mathrm{CF}$ II $\mathrm{F}\left(\mathrm{ab}^{\prime}\right)_{2}$ (Fig. $3 \mathrm{~B}$ ). Low-level binding to other preparations of normal IgG was also observed. Therefore, because of its ease of preparation, CF II F $\left(\mathrm{ab}^{\prime}\right)_{2}$ was used as the negative control for the remaining experiments. These data provide further evidence that healthy adults possess anti-Ids to anti-P antibodies.

Characterization of the purified $\operatorname{Ig} G$ antibodies to anti- $P$ $F\left(a b^{\prime}\right)_{2}$. To prove that the IgG-inhibitory antibodies in healthy adult serum and plasma were idiotype specific, they were affinity purified. Plasma from each healthy adult was treated with four immunosorbent columns as described in Methods. The second through fourth columns were used to remove other anti-P antibody inhibitors and leached column proteins from the affinity-purified material.

The epitope specificity of these affinity-purified $\mathrm{IgG}$ antibodies to anti-P antibodies was investigated. When assayed in ELISA for binding to various anti-P $\mathrm{F}\left(\mathrm{ab}^{\prime}\right)_{2}$ preparations, purified antibodies from healthy adults bound comparably to anti-P antibodies from patients and healthy adult 1 (see Fig. 4 for representative results). In contrast, purified antibodies did not bind to CF II F $\left(\mathrm{ab}^{\prime}\right)_{2}$ fragments that had been depleted of anti-P antibodies. They also did not bind to $\mathrm{F}\left(\mathrm{ab}^{\prime}\right)_{2}$ fragments of another pathogenic autoantibody, anti-dsDNA. Binding to anti-P $\mathrm{F}\left(\mathrm{ab}^{\prime}\right)_{2}$ was blocked by soluble anti-P $\mathrm{F}\left(\mathrm{ab}^{\prime}\right)_{2}$, but not by dCF II F $\left(\mathrm{ab}^{\prime}\right)_{2}$ (Table I). The unretained fraction of plasma after adsorption with $\mathrm{IgG}$ anti-P $\mathrm{F}\left(\mathrm{ab}^{\prime}\right)_{2}$ immunosorbents did not bind to any $\mathrm{F}\left(\mathrm{ab}^{\prime}\right)_{2}$ preparation. These findings confirm that healthy adults have anti-Ids to anti-P antibodies.

The ability of cognate antigen to interfere with this Id-antiId interaction was evaluated. Soluble ribosomes were used to block the binding of purified anti-Ids to anti-P F $\left(\mathrm{ab}^{\prime}\right)_{2}$. Ribosomes were chosen because they are the most efficient cognate antigen source at unmasking anti-P antibodies (13). Ribosomes blocked the binding of purified anti-Ids to preparations of anti-P $\mathrm{F}\left(\mathrm{ab}^{\prime}\right)_{2}$ from healthy adult 1 and patient 1 in a concentration-dependent manner (Fig. 5). Reduction to $50 \%$ maximal binding required a ribosome concentration of $10 \mathrm{mg} /$ $\mathrm{ml}$. This is the concentration of ribosomes that is required to
A

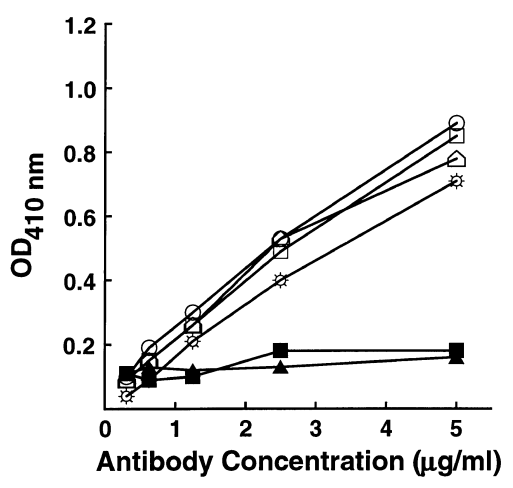

B

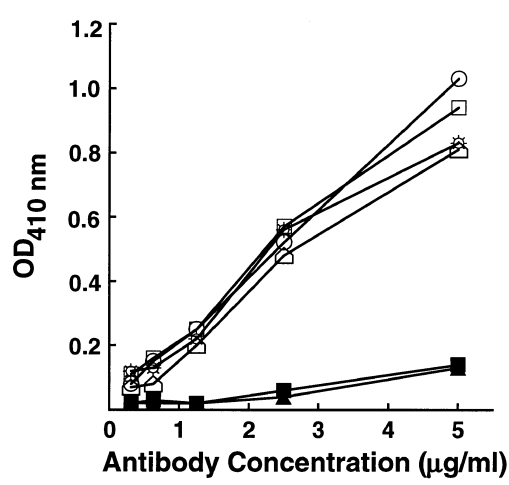

Figure 4. Anti-P Id specificity of affinity-purified IgG antibodies to anti-P $\mathrm{F}\left(\mathrm{ab}^{\prime}\right)_{2}$. Purified IgG antibodies from healthy adult $1(A)$ and $2(B)$ were assayed by ELISA for binding to $\mathrm{F}\left(\mathrm{ab}^{\prime}\right)_{2}$ fragments of anti-P antibodies from patients 1 (five-sided symbol), 2 (open square), and 3 (sunburst), anti-P antibodies from healthy adult 1 (open circle), anti-P-depleted CF II (filled square), and anti-dsDNA antibodies (filled triangle). 
Table I. Inhibition of Anti-Id Antibody Activity by Soluble Anti-P $F\left(a b^{\prime}\right)_{2}$

\begin{tabular}{lcc}
\hline & \multicolumn{2}{c}{ \%Inhibition of anti-Id activity from healthy adult } \\
\cline { 2 - 3 } Blocking agent & 1 & 2 \\
\hline Anti-P F $\left(\mathrm{ab}^{\prime}\right)_{2}$ & 67 & 77 \\
$\mathrm{CF} \mathrm{II} \mathrm{F}\left(\mathrm{ab}^{\prime}\right)_{2}$ & 3 & 0
\end{tabular}

Affinity-purified $\operatorname{IgG}$ anti-Ids to anti-P antibodies from two healthy adults were preincubated with $\mathrm{F}\left(\mathrm{ab}^{\prime}\right)_{2}$ preparations of anti-P antibodies from SLE patient 1 or CF II (each at $45 \mu \mathrm{g} / \mathrm{ml}$ ) before assay for binding to anti-P $\mathrm{F}\left(\mathrm{ab}^{\prime}\right)_{2}$ from patient 1.

completely block the binding of anti-P antibodies to cognate antigen (Stafford, H.A., unpublished observations). Control experiments were done to eliminate the possibility that these large concentrations of antigen were blocking nonspecifically. Maximal blocking of the anti-P Id-anti-Id interaction with albumin at $50 \mathrm{mg} / \mathrm{ml}$ was $13 \%$. Ribosomes used at the same concentrations did not block the interaction of normal $\operatorname{IgG~F}\left(\mathrm{ab}^{\prime}\right)_{2}$ with polyclonal anti-F( $\left(\mathrm{ab}^{\prime}\right)_{2}$. These data indicate that anti-Ids to anti-P antibodies from healthy adults are antigen blockable.

Inhibition of anti-P antibody activity by the affinity-purified IgG anti-Ids was next examined. $\mathrm{F}\left(\mathrm{ab}^{\prime}\right)_{2}$ fragments of anti-P antibodies from patient 1 were incubated with purified anti-Ids before their analysis in ribosome-specific immunoblots. AntiIds from both healthy adults inhibited anti-P antibodies in a concentration-dependent manner (Fig. 6; $A$ shows only P0 reactivity). Complete inhibition required only $50-60 \mu \mathrm{g} / \mathrm{ml}$ of the purified anti-Ids. In contrast, plasma $\mathrm{IgG}$ produced complete inhibition at $\geq 900 \mu \mathrm{g} / \mathrm{ml}$ (Fig. 1). Therefore, the activity of these anti-Ids was enriched $\sim 20$-fold with purification. To determine if all the anti-Id activity of plasma was removed by our purification procedure, plasma that was exhaustively depleted of anti-Ids was tested for inhibitory activity against anti-P $\mathrm{F}\left(\mathrm{ab}^{\prime}\right)_{2}$. No inhibition was observed, suggesting that the purified anti-Ids account for all of the anti-Id activity of plasma IgG.

Cross-reactivity of these purified anti-Ids for anti-P antibodies from different individuals was observed. Anti-Ids from healthy adult 1 efficiently inhibited antigen binding by anti-P
A

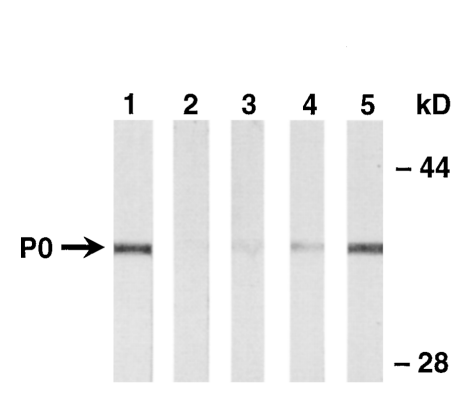

B

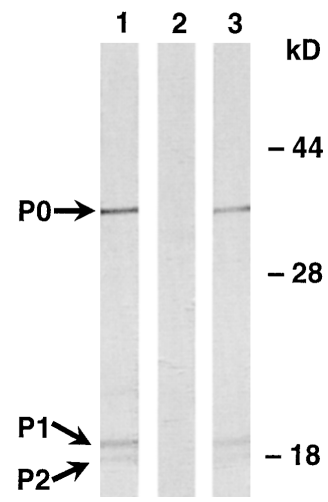

Figure 6. Inhibition of anti-P antibody activity by affinity-purified IgG anti-Ids to anti-P antibodies. Anti-P F $\left(\mathrm{ab}^{\prime}\right)_{2}$ from patient 1 (at $0.25 \mu \mathrm{g} / \mathrm{ml}$ ) were preincubated with PBS (lane 1 of each set) or purified anti-Ids to anti-P antibodies from healthy adults. Anti-P antibody activity was assayed as described in Fig. 1 B. Arrows point to the ribosomal $\mathrm{P}$ proteins. $(A)$ Anti-Ids from healthy adult 1 . Lanes $2-5$ correspond to $50,25,12.5$, and $6.25 \mu \mathrm{g} / \mathrm{ml}$ of anti-Ids, respectively. $(B)$ Anti-Ids from healthy adult 2. Lanes 2 and 3 correspond to 60 and 20 $\mu \mathrm{g} / \mathrm{ml}$ of anti-Ids, respectively.

$\mathrm{F}\left(\mathrm{ab}^{\prime}\right)_{2}$ preparations from three SLE patients (Fig. 7). These data indicate that anti-Ids from healthy adults recognize a public idiotope among anti-P antibodies from different individuals.

Detection of anti-Ids to anti-P antibodies in SLE patients. As a control for our studies in healthy adults, SLE patients without overt anti-P antibodies were studied. Sera from 10 of these patients were subjected to membrane-based affinity purification on ribosomal $P$ proteins. The affinity-purified material in the eluates and corresponding untreated control sera were assayed for anti-P antibody activity on ribosome-specific immunoblots. IgG anti-P antibody activity was detected in all treated samples, and none of the corresponding untreated sera (Table II). Based on our previous studies (15), these data suggest that anti-Ids to anti-P antibodies are present in SLE patients without overt anti-P antibodies. To prove this hypothe-

A

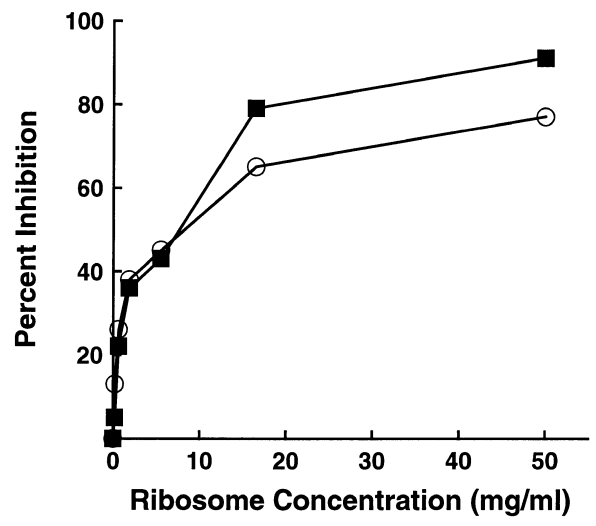

B

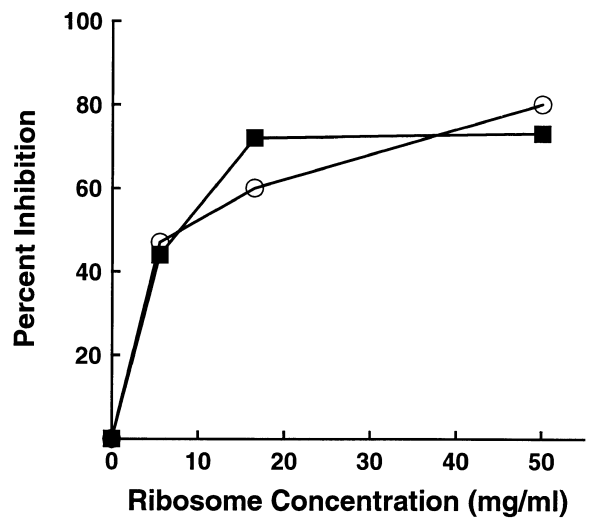

Figure 5. Inhibition of anti-Id antibody activity by cognate antigen. Affinity-purified IgG anti-Ids to anti-P antibodies from healthy adults 1 at $1 \mu \mathrm{g} / \mathrm{ml}(A)$ and 2 at $5 \mu \mathrm{g} / \mathrm{ml}(B)$ were assayed by ELISA for binding to ribosome-pretreated anti-P $\mathrm{F}\left(\mathrm{ab}^{\prime}\right)_{2}$ from patient $1(\mathrm{O})$ or healthy adult $1(\mathbf{D})$ 


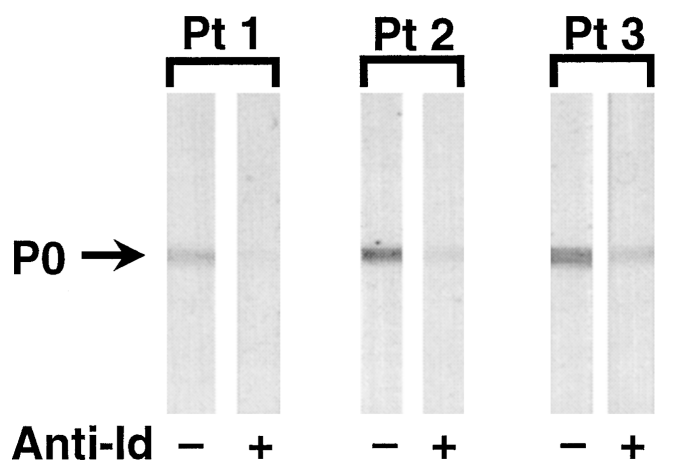

Figure 7. Recognition of a cross-reactive idiotope among anti-P antibodies. Anti-P F $\left(\mathrm{ab}^{\prime}\right)_{2}$ preparations from three SLE patients were preincubated with PBS (first lane of each set) or affinity-purified $\operatorname{IgG}$ anti-Ids (anti-Id) to anti-P antibodies from healthy adult 1 (second lane of each set, at $32 \mu \mathrm{g} / \mathrm{ml}$ ). Anti-P antibody activity was assayed as described in Fig. 1 B. Arrow points to ribosomal P0 protein.

sis, anti-Ids to anti-P antibodies were purified from the plasma of one of these patients (patient 4) in a manner analogous to that described for the healthy adults (Fig. $8 A$ ). Thus, the absence of overt anti-P antibodies in these patients is due to specific anti-Ids.

Preliminary studies were undertaken to determine if defects in the Id network for anti-P antibodies may be responsible for the serologic appearance of anti-P antibodies. Four patients who acquired and seven patients who lost overt anti-P antibodies over time were assayed for covert anti-P antibodies at the peaks and troughs of anti-P antibody expression. The membrane-based affinity purification technique was used. All patients had unmasking of their anti-P antibody activity when overt anti-P antibodies were absent (Table II). In contrast, no unmasking was observed in these patients when overt anti-P antibodies were present. Three additional patients with persistently positive anti-P sera were assayed similarly, and also showed no unmasking of their anti-P antibodies. These studies suggest that the Id network is dysfunctional when overt anti-P antibodies are present.

To determine the mechanism of anti-Id dysfunction, one patient who acquired overt anti-P antibodies during observation (patient 3 ) had her anti-Ids to anti-P antibodies purified. Since insufficient serum or plasma was available from her antiP-negative dates, plasma containing overt anti-P antibodies
Table II. Detection of Covert IgG Anti-P Antibodies in SLE Patients

\begin{tabular}{lc}
\hline \multicolumn{1}{c}{ SLE group* } & Number of patients positive for unmasking \\
\hline Persistently anti-P-negative & $10 / 10$ \\
Persistently anti-P-positive & $0 / 3$ \\
Acquisition of anti-P positivity & \\
Anti-P-negative date & $4 / 4$ \\
Anti-P-positive date & $0 / 2$ \\
Loss of anti-P positivity & \\
Anti-P-positive date & $0 / 3$ \\
Anti-P-negative date & $7 / 7$ \\
\hline
\end{tabular}

*Groups were defined by the presence of overt anti-P antibodies on conventional assays. ${ }^{\ddagger}$ Unmasking was defined by comparing eluates obtained from membrane affinity purification to a corresponding dilution of untreated autologous serum on ribosome-specific immunoblots, and by detecting greater $\mathrm{IgG}$ anti-P antibody activity in the eluates. was passed over the four affinity columns that were used to isolate anti-Ids from healthy adults. The anti-Id antibodies that were recovered bound to patient 1's anti-P antibodies (Fig. 8 $B$ ); however, they did not bind to autologous anti-P antibodies that were isolated from the same plasma sample. These results suggest that the appearance of overt anti-P antibodies in this patient resulted from the loss of autologous idiotype recognition by her anti-Ids.

\section{Discussion}

This study shows that plasma from healthy adults contain IgG antibodies to anti-P antibodies that are idiotype specific and highly cross-reactive. These anti-Ids are specific for anti-P antibodies, and are not generic anti-F $\left(\mathrm{ab}^{\prime}\right)_{2}$ antibodies. They recognize a cross-reactive idiotope on anti-P antibodies from SLE patients and healthy adults. They are largely antigen blockable. Affinity-purified anti-Ids, like plasma IgG, can mask anti-P antibodies in serologic tests. Moreover, affinity purification of these anti-Ids removed all of the anti-Id activity of plasma towards anti-P antibodies. The same Id network appears to be functional in SLE patients when overt anti-P antibodies are absent.

These results extend the findings from our original report (12). Previously, the maximal observed inhibition of anti-P an-
A

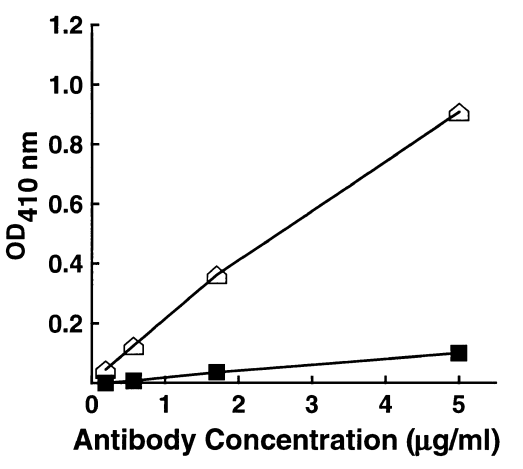

B

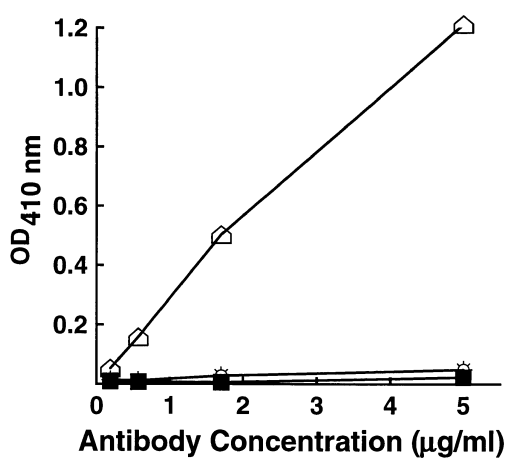

Figure 8. Anti-P Id specificity of SLE patients' affinity-purified IgG antibodies to anti-P $\mathrm{F}\left(\mathrm{ab}^{\prime}\right)_{2}$. Purified IgG antibodies from patients $4(A)$ and $3(B)$ were assayed by ELISA for binding to $\mathrm{F}\left(\mathrm{ab}^{\prime}\right)_{2}$ fragments of anti-P antibodies from patients 1 (five-sided symbol), and 3 (sunburst; patient 3 only), and anti-P-depleted CF II (filled square). 
tibody activity was $50 \%$ with $\mathrm{IgG}$ at $4-5 \mathrm{mg} / \mathrm{ml}$. Subsequent work has shown that $\mathrm{IgG}$ prepared under gentler conditions and under limited acid exposure inhibits anti-P antibody activity completely (Stafford, H.A., unpublished data). In the current study, IgG at $\sim 1 \mathrm{mg} / \mathrm{ml}$ completely inhibited anti-P antibody activity. Thus, we believe that a fraction of anti-Ids to anti-P antibodies in plasma are acid labile, and may have been denatured with our previous purification conditions.

Purification of the IgG inhibitor to anti-P antibodies from healthy adult plasma enriched the anti-Id activity 20 -fold. We expected greater enrichment. Chaotropic agents and acidic conditions may have selectively denatured a labile set of antiIds. Thus, we presume that purification resulted in a substantial loss of anti-Id activity.

Anti-Ids to anti-P antibodies in healthy adults are antigen blockable. This implies that idiotopes within the antigen-combining site, rather than the framework regions, are reacting with these anti-Ids. These results were expected, since anti-P antibodies from healthy adults can be unmasked on immunosorbents prepared with cognate antigen. Antigen-blockable anti-Ids are of two types (21). The first type (Ab2 $\beta)$ bears the internal image of the nominal antigen, while the second type $(\mathrm{Ab} 2 \gamma)$ does not. Complete antigen blocking of anti-Id activity is only observed with Ab2 $\beta$. Our results suggest that anti-Ids to anti-P antibodies in healthy adults are most likely $\mathrm{Ab} 2 \gamma$, since antigen blocking was incomplete. Blocking $<70 \%$ was only observed with ribosome concentrations fivefold greater than that required for complete blocking of anti-P antibody binding to cognate antigen. Alternatively, our results could be explained by multiple types of anti-Ids existing within a given individual.

The identification of anti-Ids to anti-P antibodies provides support for a regulatory role of the Id network in human health. Anti-Ids are well described in the normal immune response in animals (22) and humans (23). They have been described infrequently in the autoimmune response. To our knowledge, this is the third report of the purification of antiIds to autoantibodies from healthy individuals. While the existence of anti-Ids has been surmised by the unmasking of autoantibody activity in serum (24-26), most reports have evaluated only crude preparations for functional activity, i.e., neutralization or inhibition of autoantibody binding to cognate antigen (27-35). In contrast, purification has been described only for generic anti-F( $\left(\mathrm{ab}^{\prime}\right)_{2}$ antibodies (36) and anti-Ids to C3 nephritic factor (37). Because the potential for inhibition of autoantibody activity by factors other than anti-Ids, we believe that affinity purification is required to prove the existence of anti-Ids.

The origin of anti-Ids to anti-P antibodies in healthy adults is unknown. We recently showed that masked anti-P antibodies are present in children as young as 8 mo (15). Interestingly, anti-P antibodies and their anti-Ids arise in children concordantly. We hypothesize that anti-P antibodies and their anti-Ids are subject to coordinated expression such that the potential pathogenicity of anti-P antibodies is suppressed. Accordingly, we would expect anti-Ids to anti-P antibodies to be absent or dysfunctional in SLE patients with overt anti-P antibodies. Consequently, anti-P antibodies are unmasked in patients, which allows for their serologic detection, and potential pathogenicity.

Our preliminary experiments support this hypothesis. SLE patients who lack overt anti-P antibodies possess functional
anti-Ids that successfully mask their anti-P antibodies. However, the appearance of overt anti-P antibodies is associated with the loss of anti-Id regulation. In the one patient who had adequate amounts of stored plasma to purify her anti-Ids, changes in her anti-P Id repertoire appeared to be responsible for her anti-Id dysfunction. Unfortunately, serum or plasma was not available from her anti-P-negative dates to confirm that her anti-P antibodies had changed over time. In future studies, adequate plasma will be collected longitudinally from SLE patients to evaluate this hypothesis.

\section{Acknowledgments}

We wish to thank Drs. T. Carter, M. Reichlin, and D. Capra for their critical reviews of the manuscript; Dr. K. Elkon for the recombinant human ribosomal P2 cDNA; and the staff of the OASIS Graphics and Word Processing Center for their expert technical assistance.

This work was supported by the Department of Veterans Affairs (H. Stafford), the Oklahoma Chapter of the Arthritis Foundation, and a National Institutes of Health grant R01 AR-43497.

\section{References}

1. Elkon, K.B., E. Bonfa, and N. Brot. 1992. Antiribosomal antibodies in systemic lupus erythematosus. Rheum. Dis. Clin. 18:377-390.

2. Teh, L.S., and D.A. Isenberg. 1994. Antiribosomal P protein antibodies in systemic lupus erythematosus. A reappraisal. Arthritis Rheum. 37:307-315.

3. Koren, E., W. Schnitz, and M. Reichlin. 1993. Concomitant development of chronic active hepatitis and antibodies to ribosomal $\mathrm{P}$ proteins in a patient with systemic lupus erythematosus. Arthritis Rheum. 36:1325-1328.

4. Hulsey, M., R. Golstein, L. Scully, W. Surbeck, and M. Reichlin. 1995. Anti-ribosomal $\mathrm{P}$ antibodies in systemic lupus erythematosus: a case control study correlating hepatic and renal disease. Clin. Immunol. Immunopathol. 74 : 252-256.

5. Arnett, F.C., and M. Reichlin. 1995. Lupus hepatitis: an underrecognized disease feature associated with autoantibodies to ribosomal P. Am. J. Med. 99: $465-472$.

6. Martin, A.L., and M. Reichlin. 1996. Fluctuations of antibody to ribosomal "P" proteins correlate with appearance and remission of nephritis in SLE. Lupus. 5:22-29.

7. Sato, T., T. Uchiumi, T. Ozawa, M. Kikuchi, M. Nakano, and M. Arakawa. 1991. Autoantibodies against ribosomal proteins found with high frequency in patients with systemic lupus erythematosus with active disease. $J$. Rheumatol. 18:1681-1684.

8. Gaburo, N., Jr., C. Timo-laria, C. Bueno, W. Cossermelli, and E. Bonfa. 1995. "In vivo" effects of anti-ribosomal $\mathrm{P}$ protein antibodies injections into lateral ventricle of the rat brain. Arthritis Rheum. 38:S297a(Abstr.)

9. Koren, E., M.W. Reichlin, M. Koscec, R.D. Fugate, and M. Reichlin. 1992. Autoantibodies to the ribosomal P proteins react with a plasma membrane-related target on human cells. J. Clin. Invest. 89:1236-1241.

10. Koscec, M., E. Koren, M. Wolfson-Reichlin, R.D. Fugate, E. Trieu, I.N. Targoff, and M. Reichlin. 1997. Autoantibodies to ribosomal P-proteins penetrate into live hepatocytes and cause cellular dysfunction in culture. J. Immunol. 159:2033-2041.

11. Stafford, H.A., A.E. Chen, C.J. Anderson, A.G.A. Paul, E.L. Wyatt, L.A. Lee, and B.R. Neas. 1997. Anti-ribosomal and "P-peptide"-specific autoantibodies bind to T lymphocytes. Clin. Exp. Immunol. 109:12-19.

12. Stafford, H.A., C.J. Anderson, and M. Reichlin. 1995. Unmasking of anti-ribosomal P autoantibodies in healthy individuals. J. Immunol. 155:2754 2761 .

13. Pan, Z.J., and H.A. Stafford. 1996. Recombinant ribosomal P2 protein can unmask anti-ribosomal $\mathrm{P}$ autoantibodies from healthy adults. J. Lab. Clin. Med. 127:333-339.

14. Tan, E.M., A.S. Cohen, J.F. Fries, A.T. Masi, D.J. Mcshane, N.F. Rothfield, J.G. Schaller, and N. Talal. 1982. The 1982 revised criteria for the classification of systemic lupus erythematosus. Arthritis Rheum. 25:1271-1277.

15. Anderson, C.J., B.R. Neas, Z. Pan, E. Taylor-Albert, M. Reichlin, and H.A. Stafford. 1998. The presence of masked antiribosomal P autoantibodies in healthy children. Arthritis Rheum. 41:33-40.

16. Scofield, R.H., F. Zhang, B.T. Kurien, C.J. Anderson, M. Reichlin, J.B. Harley, and H.A. Stafford. 1996. Development of the anti-Ro autoantibody response in systemic lupus erythematosus. Arthritis Rheum. 39:1664-1668.

17. Andrew, S.M., and J.A. Titus. 1997. Purification and fragmentation of antibodies. In Current Protocols in Immunology. J.E. Coligan, A.M. Kruisbeek, D.H. Margulies, E.M. Shevach, and W. Strober, editors. John Wiley and Sons. 
New York. 2.7.1-2.7.12.

18. Nisonoff, A., F.C. Wissler, L.N. Lipman, and D.L. Woernley. 1960. Separation of univalent fragments from the bivalent rabbit antibody molecule by reduction of disulfide bonds. Arch. Biochem. Biophys. 89:230-244

19. Osterland, C.K., M. Harboe, and H.G. Kunkel. 1963. Anti- $\gamma$-globulin factors in human sera revealed by enzymatic splitting of anti-Rh antibodies. Vox Sang. 8:133-152.

20. Nasu, H., D.S. Chia, D.W. Knutson, and E.V. Barnett. 1980. Naturally occurring human antibodies to the $\mathrm{F}\left(\mathrm{ab}^{\prime}\right)_{2}$ portion of IgG. Clin. Exp. Immunol. 42:378-386.

21. Jerne, N.K. 1974. Towards a network theory of the immune system. Ann. Immunol. 125C:373-389.

22. Rajewsky, K., and T. Takemori. 1983. Genetics, expression, and function of idiotypes. Annu. Rev. Immunol. 1:569-607.

23. Geha, R.S. 1985. Idiotypic-anti-idiotypic interactions in man. Am. J. Dis. Child. 139:417-420.

24. Lutz, H.U., and G. Wipf. 1982. Naturally occurring autoantibodies to skeletal proteins from human red blood cells. J. Immunol. 128:1695-1699.

25. Guilbert, B., G. Dighiero, and S. Avrameas. 1982. Naturally occurring antibodies against nine common antigens in human sera. I. Detection, isolation, and characterization. J. Immunol. 128:2779-2787.

26. Gilles, J.G., and J.M. Saint-Remy. 1994. Healthy subjects produce both anti-factor VIII and specific anti-idiotypic antibodies. J. Clin. Invest. 94:14961505 .

27. Zouali, M., and A. Eyquem. 1983. Expression of anti-idiotypic clones against auto-anti-DNA antibodies in normal individuals. Cell Immunol. 76:137147.

28. Tandon, N., D.R. Jayne, A.M. McGregor, and A.P. Weetman. 1992. Analysis of anti-idiotypic antibodies against anti-microsomal antibodies in patients with thyroid autoimmunity. J. Autoimmunol. 5:557-570.
29. Rossi, F., and M.D. Kazatchkine. 1989. Antiidiotypes against autoantibodies in pooled normal human polyspecific Ig. J. Immunol. 143:4104-4109.

30. Berchtold, P., G.L. Dale, P. Tani, and R. McMillan. 1989. Inhibition of autoantibody binding to platelet glycoprotein IIb/IIIa by anti-idiotypic antibodies in intravenous gammaglobulin. Blood. 74:2414-2417.

31. Rossi, F., D.R. Jayne, C.M. Lockwood, and M.D. Kazatchkine. 1991 Anti-idiotypes against anti-neutrophil cytoplasmic antigen autoantibodies in normal human polyspecific IgG for therapeutic use and in the remission sera of patients with systemic vasculitis. Clin. Exp. Immunol. 83:298-303.

32. Pall, A.A., M. Varagunam, D. Adu, N. Smith, N.T. Richards, C.M. Taylor, and J. Michael. 1994. Anti-idiotypic activity against anti-myeloperoxidase antibodies in pooled human immunoglobulin. Clin. Exp. Immunol. 95:257-262.

33. van Doorn, P.A., F. Rossi, A. Brand, M. van Lint, M. Vermeulen, and M.D. Kazatchkine. 1990. On the mechanism of high-dose intravenous immunoglobulin treatment of patients with chronic inflammatory demyelinating polyneuropathy. J. Neuroimmunol. 29:57-64.

34. Liblau, R., P. Gajdos, F.A. Bustarret, R. el Habib, J.F. Bach, and E. Morel. 1991. Intravenous gamma-globulin in myasthenia gravis: interaction with anti-acetylcholine receptor autoantibodies. J. Clin. Immunol. 11:128-131.

35. Caccavo, D., F. Vaccaro, G.M. Ferri, A. Amoroso, and L. Bonomo. 1994. Anti-idiotypes against antiphospholipid antibodies are present in normal polyspecific immunoglobulins for therapeutic use. J. Autoimmunol. 7:537-548.

36. Silvestris, F., A.D. Bankhurst, R.P. Searles, and R.C. Williams, Jr. 1984 Studies of anti-F $\left(\mathrm{ab}^{\prime}\right)_{2}$ antibodies and possible immunologic control mechanisms in systemic lupus erythematosus. Arthritis Rheum. 27:1387-1396.

37. Tsokos, G.C., A.E. Stitzel, A.D. Patel, M. Hiramatsu, J.E. Balow, and R.E. Spitzer. 1989. Human polyclonal and monoclonal IgG and IgM complement 3 nephritic factors: evidence for idiotypic commonalty. Clin. Immunol. Immunopathol. 53:113-122. 